\title{
The Association between IT Related Trainings and IT Investments in Malaysia
}

\author{
Marjan Mohd Noor ${ }^{1} \&$ Kogilavani Apadore ${ }^{2}$ \\ ${ }^{1}$ School of Business, Al-Bukhary International University, Kedah, Malaysia \\ ${ }^{2}$ Faculty of Business \& Finance, Universiti Tunku Abdul Rahman, Malaysia \\ Correspondence: Marjan Mohd Noor, School of Business, Al-Bukhary International University, Jalan Tun Abdul \\ Razak, 05200 Alor Setar Kedah, Malaysia. E-mail: marjan@aiu.edu.my
}

Received: February 18, 2013

Accepted: December 6, 2013

Online Published: December 18, 2013

doi:10.5539/ijbm.v9n1p63

URL: http://dx.doi.org/10.5539/ijbm.v9n1p63

\begin{abstract}
This study aims to examine whether there are association between IT related trainings and IT investments in the Malaysian technology-based companies. This study uses two types of IT related trainings namely intermediate IT trainings, and advanced IT trainings which have never been tested with IT investments in previous studies. The data were collected via annual reports in 2010 from 104 technology-based companies listed in Bursa Malaysia. Results from univariate test show that IT-based companies are actively involved in IT investments compared to engineering based companies. Result for intermediate IT trainings from linear regression shows, non-significant but result for advanced IT trainings are significant but with a weak association. Thus, result for second hypothesis is partially supported, but weak association with IT investments. From the same regression, result for third hypothesis also can be concluded that advanced IT trainings are significant but weak association with IT investments.
\end{abstract}

Keywords: ICT, IT, information technology, investment, training

\section{Introduction}

\subsection{Background of the Study}

The purpose of this study is to examine the association between IT related trainings and IT investments. IT is very important to many business organizations, as in organizations. Survival and ability to achieve the goals of business strategy is difficult if the execution is not supported by an extensive use of information technology in today's environment. Due to that situation, many organizations decided to make investments in IT since it may contribute a lot of benefits to the company in the long run. This statement is supported by several literatures by saying that there are some reasons why organizations in particular invested in IT (Brynjolfsson, 1993, 1994; Ashrafi \& Murtaza, 2008). Apart from a need to create wealth for organization, improve output levels in production and service delivery, IT investments also open up opportunities to them to produce quality products and services and to control communication activities in order to achieve their customer satisfaction. Business organizations invest in information technology because they are necessities in doing business and these necessities are driven by industry level changes (ie., rapid changes information and stiff competition). Besides that, several literature studies also state that investment in IT assets has also made a particularly marked contribution to economic growth across G7 economies in the late 1990s (Colecchia \& Schreyer, 2002; OECD, 2003) and improved productivity, competitiveness and citizen engagement (Kodakanchi et al., 2006). However, this study will not focus on the benefits of IT to business productivity, competitiveness, and citizen engagement. The researcher will take into account other factors or elements that determine the IT investments which might lead to increasing business productivity in an organization.

This study is consistent with the United States General Accounting Office (GAO) in 2000, in which it provides an Information Technology Investment Management (ITIM) framework which enhances this guidance by identifying critical processes for successful IT investments and organizing these processes into a framework of increasingly mature stages. ITIM is established in order to be a road map companies can use for improving their IT investments management process. In order to achieve the effectiveness of the investment made, GAO noted, however the ITIM can only succeed if its implementation is concomitant with other good management practices 
such as human capital, training, IT architecture, and software management. These four types of management practices require employees' knowledge and skills in ensuring that IT usage is conducted effectively. Since the investments in IT involve high provision (Khor, 1999), employees must have sufficient IT skills so that it will increase productivity as well as provide good returns to the organizations (Bates, Holton \& Seyler, 1996). Studies for Canada, for example, have found that use of advanced technology is associated with a higher level of skill requirements (Baldwin \& Diverty, 1995). Therefore, the management of organization plays an important role in providing more IT trainings to enhance the IT skills of the employees (Baldwin et al., 2004). This is the central issue of this study and particularly observable in a specific type of industry.

Malaysian technology sector is selected as it has been identified as the biggest sector involved with the use of information technology compared to other industries (Morris, 2003). As the technology based company plays with high technology of components and applications of computer program, knowledge and skills among employees are really needed to handle all the IT components and IT applications. It is very important because without having enough knowledge and skills, companies will find difficulties in achieving their business goals due to the IT adoption which should be in line with good quality asset of their workforce. In order to produce skilled and competent employees in the handling of high technology components, effective IT training programmes should be provided by the management of an organization to its employees.

Based on the above description, it is acknowledged that IT training for employees is an important element that organizations should address to ensure that the training can produce quality IT input to their workforce in which it can also provide good returns to an organization. According to Brynjolfsson and Hitt (2000), for IT investments to be worthwhile, organizations need to spend additional resources in training its workforce to improve the production process. It should be taken seriously by the organization since many Human Resource Departments of organizations nowadays view the transfer of training in which the revaluation has been made more seriously and find that the rate of transfer of skills after the training is low compared to the amount of investment made. This scenario resulted in the organization working to identify what are the best methods to improve the training programmes for employees (Bates, Holton \& Seyler, 1996). In order to use IT effectively and to integrate it in organizations, the organizations should not only make investment in IT, but also provide adequate training and support to become fully capable at using these technologies (Goktas et al., 2009).

\subsection{Problem Statement}

Since IT investments involve the high provision (Khor, 1999), employees must have sufficient IT skills (Brynjolfsson and Hitt, 1998; Arabsheibani et al., 2004; Moriones \& Lopez, 2007) so that it will increase productivity as well as provide good returns to the organizations (Bates, Holton \& Seyler, 1996). Therefore, the management of organization plays an important role in providing more IT trainings to enhance the IT skills of the employees (Baldwin et al., 2004).

However, most of the literature studies found are focused on such impact of IT investments on productivity improvement (Turcotte \& Rennison, 2004; Hall, et al, 2011) on the economic growth (OECD, 2004; Abas, 2005; Sharpe, 2006) and only little prior studies reviewed its association with IT trainings. However, the studies do not specifically examine on the specific types of IT training provided to employees (Colecchia \& Schreyer, 2002; Turcotte \& Rennison, 2004). IT trainings should be varied as the levels and background of employees who come from different divisions, the level of IT skills and IT training to employees should be different based on the levels of IT training and specific IT skills (Atasoy, 2011). Since most previous studies did not examine the associations of IT related trainings specifically with IT investments, so this study will examine whether there are associations between IT related trainings and IT investments in the Malaysian technology based companies.

\subsection{Research Objective}

IT related trainings are believed to have the ability to analyse further on the associations in the IT investments made by Malaysian technology based companies. IT related trainings have even been widely accepted as one of the most important elements that every organization needs to consider in achieving good returns on investments made in IT (Brynjolfsson \& Hitt, 2000). In specific, this study intends to examine whether there are associations between IT trainings and IT investments in the Malaysian technology based companies.

\subsection{Significance of the Study}

This study contributes to the literature in the following ways. Firstly, it contributes to the level of management of technology based companies in Malaysia. Particularly, it sheds a new light upon the associations between IT related trainings and IT investments. Second, this study will provide insight into the extent of organizations involvement in providing adequate IT trainings to employees in accordance with the IT investments made. The result of this study can be useful for top management level in organizations to take appropriate approach to IT 
related training programmes in order to ensure that the IT investments they have made are worth (Brynjolfsson \& Hitt, 2000). Lastly, it is hopeful that this vital study can help to add on to the existing literature of IT related trainings specifically, those that can be used as a reference or guidance for future research to expand its scope to all public and private sectors in Malaysia. This is because, most of the literature studies did not review in the association of IT related trainings with IT investments. Given that the growth of IT boom has greatly influenced the development in organizations nowadays, further research on the association of IT related trainings with IT investments is seen important as IT investment does not only occur in technology companies alone but in all companies of all sectors. However, this study is customized to gain better understanding on technology companies as the context of technology sector is very close to IT development (Morris, 2003).

\subsection{Limitation of the Study}

There are a few limitations identified in this study. Firstly, the sample only consists of 104 companies in which the study is only based on one year of listed companies in the Bursa Malaysia. This is because IT trainings may be given to employees for two or three years before the companies decide to invest in IT during the year 2010. More precisely, the results may be more significant if the number of IT trainings also takes into account two or three years before the companies do their IT investments. Therefore, this small sample size is not sufficient and should not be used to represent the association between IT related trainings and IT investments as a whole. Secondly, the samples were selected from one sector only which is the technology sector. By using only one sector, it is not sufficient to support the first and second hypotheses that have been expected. Due to the factor that the disclosure of the number of employees was done by only one company, the idea of IT trainings which is more related to employees can not be generalized.

\section{Literature Review}

\subsection{Definition of IT Trainings}

According to US Fairfax County Public Schools (2004), IT trainings can be defined as a learning process related to software and high-end technical applications, network administration operating systems, and cable technologies and performs related duties as required or assigned. However, this definition is focused on the IT specialists. Usually, IT training courses include comprehensive training from basic to advanced IT skills and may include trainings to learn to master a software system. Those trainings are geared to those who are new to the IT knowledge as well as to those who wish to improve their knowledge and existing skills for employment or specialized tasks.

Waema (2002) described some professions that are involved in training ICT human resource development, such as computer science, computer engineering, information technology, electrical and electronic engineering, telecommunications engineering and information science. Consistent with Waema (2002), the researcher assumes that this study is accurate to be conducted in technology sector since all the features of technology sector described by Waema are associated with it. Given the rapid spread of computers and computer based technologies, it has generated a continual need and demand to provide opportunities for employees to update their technical skills. The failure to provide training to employees could cause the companies to pay more in order to ensure that operations can be performed in the long run (Auer, 1995).

\subsection{The Association between IT Related Trainings and IT Investments}

Some previous studies indicate that IT investments are often associated with increased in training efforts. Brynjolfsson and Hitt (1998) found that companies which invest in IT intensively train their employees more intensively for education in order to empower their skills and knowledge. Bartel and Sicherman (1998) also argue that higher rates of technological change on industry level are associated with a higher percentage of the workforce trained. The rapid changes of information technology show that organizations invest more in training for their employees in response to the new technology they invested in order to make changes in its management of corporate technology (Brynjolfsson \& Hitt, 2000). The rapid growth of IT usage today has been associated with a variety of changes to their internal processes, such as organizational structure, job design, and requisite employee skills for the purpose of improving the quality of management (Arabsheibani et al., 2004; Moriones and Lopez, 2007).

The main purpose of the information technology system is to be a catalyst for the information management in the organization. In fact, the organization is also able to achieve the goals by providing managers with insight on the organization's operations so that they can control, manage and plan more effectively and efficiently (Stair \& Reynold, 1999). In other words, expertise and skills of the individual employees are necessary to ensure that the IT operation system is managed with utmost efficiency. This is important and should be of concern to the organization because it is closely related to IT investments made by the organization, whether companies are 
obtaining adequate returns on their information technology investments or otherwise. Berman et al. (1994) found that there was an increase in skill requirements in the manufacturing sector when IT was introduced in the late 1980s. The use of IT is quite low and public awareness on the IT application is very minimal when IT tools more introduced at the earliest stages. Due to that situation, the IT training programme is considered as the heart of excellence to the survival of an organization in a competitive market (Hazani, 2004).

\subsection{The Importance of IT Related Trainings to Employees}

Almost every business nowadays is carried out by an organization controlled by the technology. The advancement of IT has contributed to the increase in management and administration process of the organization. Tapscott (1996) and Fisher (1993) emphasized that IT is an important mechanism in an organization. Accordingly, in order to realize the advancement of IT, training programme was seen as a mechanism that best equipped employees with skills in managing IT in an organization. This is because in spite of the existence of IT infrastructure in an organization, a quality management and administration process will not be achieved successfully if the amenities provided were not accompanied with the right implementation. Generally, employees will not reach their full potential and higher levels of productivity will not be achieved unless they are adequately trained. A poorly trained work force will eventually lead to poor performance and result in costly mistakes (Wilke, 2006). Indirectly, the productivity of a business increases by the increase in the skills of employees.

Global competition and technological advancements which are constantly changing are seen to change the current situation of working environment (Ford \& Weissbein, 1997). This is because in the face of global competition and technological change that are rapidly growing, the organization is prompted to always be aware of the importance of training and technology to its employees (Ford \& Weissbein, 1997). This awareness is important as the training programme will change for the better in the restructuring and reorganization of an organization (Anizan, 2006). Given the large impact of IT to the transformation of management and administration of an organization, it has become an essential requirement for organizations to comply with technology and to handle it so as to improve their performance. In order to create effective IT operations, organizations must realise that training employees who will be able to use IT, is an important factor that need to be emphasized since it can bring success to any organization and given mainly for the purposes of familiarizing new employees of the company or updating and enhancing the knowledge of existing employees (Shafique \& Mahmood, 2010; Hamidi et al., 2011).

\subsection{The Implications of IT Related Trainings on IT Investments}

Logically, what are the purposes of a company to invest in IT? Generally, IT investments are intended to harness the potential of IT towards improvements and effectiveness of the delivery system in organizations in which this implementation should be followed by adequate IT trainings for employees to improve the level of their IT management process. The purpose is that IT investment will be able to produce high returns to organizations through improvisations in their delivery system. In addition, an efficient IT management would also assist in the production of products with a high level of speed and responsiveness (Brynjolfsson, 1993).

Every decision of IT investments must go together with proper planning because IT investment decisions are seen in general expensive which incurred high costs of investments (Khor, 1999; Connolly, 1999). For organizations to obtain a good return from their IT investment, they need to take responsibility in providing adequate funding for IT training for its employees (Brynjolfsson \& Hitt, 2000). Each employee who will be expected to use, manage and or maintain the IT system should be well trained to contribute in establishing an appropriate IT strategy to be implemented. Scholars show that organizations that do not prioritize IT training programmes have employees with the least IT skills and IT confidence in which it resulted as a major factor in the poor use of IT infrastructure in the organization (Davey, 2007).

Studies were conducted by Gorriz and Castel (2010) through the relationship between human resources and information and communication technologies in Spanish firms; results of the study show that there is a strong relationship between the capacity and skills of workers with IT organizations that incorporate new technologies. Specifically, they stress that firms adopting IT that required qualified and well-trained employees, are able to respond to the needs of new technology invested in order to achieve higher levels of productivity and efficiency. This result indicates that a variety of IT trainings should be coordinated across the organization in achieving its efficiency targets from the task implementation (Atasoy, 2011). 


\subsection{Hypotheses Development}

\subsubsection{The Nature of IT Investments in Technology Sector}

In Malaysia, IT plays a major influence in economic growth and community life. In order to ensure the development of advanced IT is concomitant with the national economic growth, the Malaysian government has invested enormously in IT over several years. In the Ninth Malaysia Plan for the period of 2006 to 2010, a total of U.S. $\$ 6$ billion has been allocated for IT development throughout the country. Investment made by public and private sectors during this period mostly focused on IT infrastructure. This kind of effort is a part towards the creation of network facilities and services to promote the efficient and rapid diffusion of IT in the economy more widely.

Technology sector is seen as the biggest sector involved with the use of information technology compared to other sectors (Morris, 2003). Technology sector may consists of IT-based and engineering-based companies that contain businesses revolving around the manufacturing of electronics, oil and gas, biotechnology, automobile manufacturing, semiconductor, creation of software, computers or products and services relating to information technology and telecommunications (Pravitt, 1984; Paytas \& Berglund, 2004). Meaning that, the technology sector will predominantly invest in IT since IT is an essential component in this sector. From this classifications between IT-based company and engineering-based companies, it can be interpreted that IT-based company will be assumed as the main company that will be involved more in the use of information technology and communications which needs greater IT investments as compared to engineering based companies. Therefore, the hypothesis is as followed:

$\mathrm{H}_{1}$ : IT-based companies are actively involved in IT investments compared engineering-based companies.

\subsubsection{The Nature of IT Related Trainings in the Association of IT Investments}

Generally, IT investments made are intended to harness the potential of IT towards improvements and effectiveness of the delivery system in organizations. To ensure its effectiveness, the implementation must be accompanied by several measures that can be used to improve IT management levels. Having proper investment management will help organizations to earn a good return in future. In general, any trainings and development programs provided by the organization to the employees are adequately enough to help organizations to achieve their investment goals because the training program has been indicated as one of the best forms of motivation that can help organizations to produce more skilled employees and IT professionals (Zaharias \& Poulymenakou, 2003; Rocheleau, 2006) especially in the technology sector. In order to empower employees in IT skills, IT related trainings can be the most important human resource tools (OECD, 2008). A survey conducted by the Knowledge Society Agency (UMIC) (2008) shows that employees from public sector in Portugal are actively involved in IT related training programs. Improving public sector staff's IT skills has been a priority to many OECD countries and it was proved by Australia in 2007 where it made IT training programs as a key strategy for improving and ensuring future IT skills in the Australian public service (OECD, 2008).

IT usage is not limited to the IT department people, but its use is widespread to all departments since it is utilized in the whole organization. Given the background of employees who come from difference parts and different IT level skills, IT trainings provided should be more specific which is suitable with the IT competency and IT level of each individual employee (Atasoy, 2011). According to Hubbard (2005) and Atasoy (2011), the skills of users are different and they are classified into basic IT skills, intermediate IT skills, and advanced IT skills. Specifically, basic skills include integrating with email and Internet, using operating system, using basic word processing, spread sheet, presentations, creating Websites (Hubbard, 2005; Kolding \& Kroa, 2007; Bass, 2007), copying and transferring files or folder and using copy or paste command (Atasoy, 2011). Intermediate or medium skills include creating basic media, using various social-networking applications and audio chat (Hubbard, 2005), zipping files or folders as well as connecting devices to computer (Atasoy, 2011). Advanced IT skill is defined for users who have advanced IT knowledge and who know a programming language (e.g., database, JavaScript, ERP), connecting computers and networks, creating advanced web design, as well as problem solving involving internet and computers (Hubbard, 2005; Atasoy, 2011).

In short, this issue has to be addressed quickly to make IT trainings in line with the objectives of IT investments because the success of this implementation can provide a real business value to organizations. For this purpose, this research will be conducted to see the extent of association between IT related trainings and IT investments in Malaysian technology based companies. Thus, the hypothesis developed is as follows:

$\mathrm{H}_{2}$ (a): There are associations between IT related trainings and IT investments in Malaysian technology based companies 
We suppose that IT related training programs will involve employees in companies investing in IT. Since several studies found that there is a significant association between training programs provided with the investment made by organizations (Bates, Holton \& Seyler 1996), these prior studies are suitable to be applied in the IT environment. This is because, in order to use IT effectively and to integrate it in organizations, the organizations should not only make investments in IT, but also provide adequate and necessary training and support to enable their employees to become fully capable at using these technologies (Goktas, et al., 2009). As the use of IT is closely related to capabilities and competencies of different types of users (Hubbard, 2005; Atosay, 2011), this research is divided into two types of IT related trainings namely intermediate IT trainings, and advanced IT trainings in answering the $\mathrm{H}_{2}$ (a) hypothesis. However, basic IT skills which were proposed by prior studies are not included in this study by taking into account that employees from the technology sector have at least a little basic knowledge and skills in IT.

Intermediate IT training refers to intermediate users including the use of various applications such as navigating a computer's filesystem (Hubbard, 2005; Atasoy, 2011), creating basic media, using various social-networking applications and audio chat (Hubbard, 2005), as well as connecting devices to computer (Atasoy, 2011). Due to limited literature studies defining intermediate IT trainings for intermediate users, this study only relied on the concept of computer skills defined by Hubbard (2005) and Atasoy (2011).

Advanced IT Trainings refer to skills of knowing a programming language, connecting computers to networks and problem solving involving Internet and computers (Atasoy, 2011). Other previous studies indicate that advanced IT trainings are related to the skills of using common generic software tools (e.g, Enterprise Application Software, OLAP) and specialized tools supporting business functions, such as accounting, sales and marketing or production applications (Kolding \& Kroa, 2007). Usually, employees who already have the necessary skills will be selected by the employer to pursue advanced IT trainings in order to enhance their job performance. This is because advanced IT trainings are not only to train employees to be good in programming but also in fixing any software conflicts (Mann, 2003) as well as knowing how to repair computer hardware and problem solving of data security. The effort to increase the productivity from the IT investments, not only requires the effective IT facilities but also concomitant with more advanced IT skills of the workforce. Organizations need to be serious about the importance of having advanced IT skills among itsemployees; otherwise it can give negative impact on the IT development in the organizations.

Given that many technology based companies engaged in high technology of IT components that require advanced IT skills, so the intermediate skills will be ignored. This study is expecting that employees will be more exposed to advanced IT trainings compared to intermediate IT trainings. Thus, the hypothesis developed is as follows:

$\mathrm{H}_{2}$ (b): The more advanced the IT trainings, the more investments in IT are made by technology based companies.

\section{Research Method}

\subsection{Data Collection}

Data were collected from the annual reports which were obtained from the Bursa Malaysia's website (www.bursamalaysia.com) for the period of 2010. This study couldn't be conducted based on the year 2011 due to the unpublished annual report of the technology based companies. Annual reports, which were obtained from Bursa Malaysia's website, have also been used as supplementary sources. In addition, technology sector is selected since it is indicated as the largest sector that is closely related to IT usage (Paytas \& Berglund, 2004).

\subsection{Population and Sample}

The population of this study consisted of Malaysia Public Listed Companies. 104 proportional samples of companies were randomly selected from technology sector listed on the Main Market and ACE Market of Bursa Malaysia. There are 978 companies (see Table 1) listed in Bursa Malaysia as at 31 December 2010. 865 (88\%) of them are listed on the Main Market, and 113 (12\%) are listed on the ACE Market. According to classification of applicants or listed issuers for the Main Market and ACE Market provided by Bursa Malaysia Securities Berhad, technology sector is identified as a sector that provides information technology solutions which fulfils the research requirements that focuses on companies engaged in IT components. Therefore, only technology sector is selected for further research whilst other sectors are excluded. There are only 104 listed companies of technology sector available for the sampling. The 31 companies studied in this research were identified from Main Market and 73 companies identified from ACE Market. Through this study, the technology sector is divided into two types of companies, IT-based company and engineering-based company (Pravitt, 1984). Based 
on the list of Malaysia technology public listed companies, it has not been specifically classified between IT- based and engineering-based companies. Therefore, this study has classified the technology companies into IT-based company and engineering-based company based on the concepts and definitions from previous studies.

IT-based company is identified as a company involved in IT activities such as "process, deliver, and display information electronically", as well as produce equipment, software and services that enable those ICT activities (OECD, 2008). Whereas engineering-based company is identified as a company that consists of major basic branches of chemical engineering, civil engineering, electrical engineering and mechanical engineering (Frodeman, et al., 2010).

The result from this classification indicates that there are 59 IT-based companies identified from 14 companies in Main Market list and 45 companies identified from ACE Market. Whilst there are 45 engineering-based companies identified from 17 companies in Main Market and 28 companies from ACE Market. Table 2 below provides clear picture on the classification of Malaysian Technology Company.

Table 1. Classification of listed companies of Malaysian public listed companies in 2010

\begin{tabular}{clccc}
\hline No & \multicolumn{1}{c}{ Sectors Classified } & Main Market & ACE Market & Total \\
\hline $\mathbf{1}$ & Closer Ends Funds & 1 & - & 1 \\
$\mathbf{2}$ & Construction & 50 & - & 50 \\
$\mathbf{3}$ & Consumer Products & 147 & 1 & 148 \\
$\mathbf{4}$ & Exchange Traded Funds & 5 & - & 5 \\
$\mathbf{5}$ & Finance & 37 & 1 & 38 \\
$\mathbf{6}$ & Hotels & 5 & - & 5 \\
$\mathbf{7}$ & Industrial Products & 260 & 18 & 278 \\
$\mathbf{8}$ & IPC & 7 & - & 7 \\
$\mathbf{9}$ & Mining & 2 & - & 2 \\
$\mathbf{1 0}$ & Plantation & 44 & - & 44 \\
$\mathbf{1 1}$ & Properties & 88 & - & 88 \\
$\mathbf{1 2}$ & Reits & 13 & - & 13 \\
$\mathbf{1 3}$ & Technology & 31 & 73 & 104 \\
$\mathbf{1 4}$ & Trading / Services & 175 & 20 & 195 \\
\end{tabular}

Table 2. Classifications of Malaysian technology based companies

\begin{tabular}{|c|c|c|c|}
\hline & IT Based Companies & Engineering Based Companies & Total \\
\hline Main Market & 14 & 17 & 31 \\
\hline ACE Market & 45 & 28 & 73 \\
\hline Total & 59 & 45 & 104 \\
\hline
\end{tabular}

\subsection{Selection of Measures}

IT investment is the dependent variable in this study. The analysis of IT investments uses one control variable namely net cash investing activity in IT which is determined from the net cash investing activity in the financial statement. Subsequently, the control variables are observed based on quantitative data and will be recorded and analysed in order to investigate the total amount related to IT investments in technology based companies. In order to investigate the nature of association of IT investments and IT related trainings, several groups of IT trainings will be used to see the occurrence of each type of IT trainings attended by employees in technology based companies. Two groups of IT trainings that are considered in the IT related trainings are intermediate IT training, and advanced IT training.

All these variables are selected in accordance with previous studies carried out by different researchers. The two groups of IT related trainings that are considered sufficient to cover the key dimension types of IT related training programmes are intermediate IT trainings (Wilson et al., 1998), and advanced IT trainings (Wilson et.al., 1998; Sullivan et al., 2007). The frequency of IT trainings for a company will be determined by examining word by word related to the IT trainings with regard to other words such as events, seminars, and workshops. Most of the companies' training activities attended by employees are very much likely to be disclosed in the early 
attachments of companies' annual reports such as the attachment of Chairman's Statement, Business Review, Event Highlights or Calendar, and Corporate Social Responsibility disclosure. In order to ensure that all identified trainings are related to IT trainings, the researcher examines every word of training in more detail via the Internet. For the purpose of classification of information related to IT trainings, the researcher will determine the frequency of IT trainings attended by employees of each company based on intermediate IT trainings and advanced IT trainings.

Table 3. Types of variables

\begin{tabular}{lc}
\hline Dependent Variable & \\
Net Cash for IT Investing Activities & NCIA (IT) \\
Hypothesis Variables & IIT \\
Intermediate IT Trainings & AIT \\
Advanced IT Trainings & \\
Control Variables & ROA \\
Return on Assets & TA \\
Total Assets & SUB (IT) \\
Number of IT Subsidiaries & \\
\hline
\end{tabular}

\section{Results}

\subsection{Descriptive Statistics}

Descriptive statistics for both the dependent and independent variables are illustrated in Table 4.

Table 4. Descriptive statistics of dependent and independent variables

\begin{tabular}{lcccc}
\hline \multicolumn{1}{c}{ Variables } & Minimum & Maximum & Mean & Standard Deviation \\
\hline NCIA (IT) & 0.0000 & 17.9435 & 8.6938 & 6.4515 \\
TA & 9.4996 & 21.3307 & 17.7483 & 1.5049 \\
ROA & -64.6355 & 0.4909 & -0.6887 & 6.3453 \\
SUB (IT) & 0 & 21 & 3 & 4.2677 \\
IIT RATIO & 0 & 1.0309 & 0.0198 & 0.1423 \\
AIT RATIO & 0 & 78.6035 & 1.5984 & 7.7763 \\
\hline
\end{tabular}

Table 4 shows the descriptive statistics from the 104 sample companies for the year 2010 . The minimum value of NCIA (IT) is RM 0 while the maximum value is 17.94 . The value of mean is 8.6938 . This would mean that the rates of return on IT investments in technology based companies are often high or positive. It seems that many IT investments are likely to provide their companies with significant potential opportunities in addition to their estimated direct benefits. The condition is the same for total assets (TA). For the year 2010, the minimum value of $\log$ of write of TA is 9.5 while the maximum value is 21.33 . The data is expected $95 \%$ of confidence interval within the positive average of 17.75 due to an increase in the assets of the companies in $2010.66 \%$ of companies have invested in IT assets where these investments have contributed to the increase in the overall total assets during the year. However, the mean value for ROA is at $-68.87 \%$ which means that the rates of return on asset in technology based companies are often low or negative. $73 \%$ of companies lose in their income when they first invested in a property and for the purpose of enhancing or improving an existing property which led them to a negative return on investment. That is why the minimum value for ROA is at -64.64 .

Meanwhile, the result also shows that the mean value for SUB (IT) is 3 . This means that the companies generally have their IT subsidiaries aimed at helping them to adapt new information technology requirements more easily. Further, table 4 also shows that $159.84 \%$ of the technology based companies were involved in advanced IT trainings during the year compared to intermediate IT training which shows the average at only $1.98 \%$. It was expected that $95 \%$ would be within 7.7763 standard deviations of the mean 1.5984 . This suggests that most companies in the sample are adopting more advanced IT knowledge such as Enterprise Resource Planning software that may help companies to reduce their costs and also Supply Chain Management software that can help 
increase productivity, efficiency of inventory controls, and increase sales through closer relationships and faster delivery times.

\subsection{Independent Sample Test Analysis}

The independent sample test is appropriate when different subjects have performed in each of the different conditions. In this study, technology based companies may consist of IT-based companies and engineering-based companies, which supports the prior studies by Pravitt (1984) and Paytas and Berglund (2004). Given that the technology sector is seen as the biggest sector involved with the use of information technology compared to other sectors (Morris, 2003), so IT-based companies are assumed to be actively involved in IT investments compared to engineering-based companies.

In order to test either IT-based companies are actively involved in IT investments or not, the t-test is conducted to compare which types of companies will have the larger mean. Table 5 shows that the mean value of IT-based companies is 11.9948 which is larger than the mean value of engineering-based companies which is only at 4.3657. Given the df value, 79 and the t-value, 7.0761, both of the values are large enough to be significant and support the larger mean of IT-based companies. From this results, it can be concluded that IT-based companies are actively involved in IT investments compared to engineering companies, supporting the first hypothesis.

Table 5. T-Test of two samples assuming unequal variances

\begin{tabular}{lcc}
\hline & IT Based Companies & Engineering Based Companies \\
\hline Mean & 11.9948 & 4.3657 \\
Variance & 20.4431 & 36.7150 \\
Observations & 59 & 45 \\
Hypothesized Mean Difference & 0 & \\
Df & 79 & \\
$\mathbf{t}$ Stat & 7.0761 & \\
$\mathbf{P}(\mathbf{T}<=$ t) one-tail & 2.6710 & \\
$\mathbf{t}$ Critical one-tail & 1.6644 & \\
$\mathbf{P}(\mathbf{T}<=$ t) two-tail & 5.3421 & \\
$\mathbf{t}$ Critical two-tail & 1.9905 & \\
\hline
\end{tabular}

\subsection{Correlation}

Table 6 presents the correlations result among the variables in the test models. The table indicates that the IT investment for 2010 is negatively associated with total assets. However, it is positively associated with the return on assets, number of companies' IT subsidiaries, intermediate IT trainings, and advanced IT trainings. Intermediate IT trainings are positively associated with company size measured by total assets while advanced IT trainings are negatively associated with total assets. However, both IT trainings (intermediate and advanced) are positively correlated with profitability. It could be argued that companies in IT related business do not invest much in physical assets but they would rather invest in non-physical assets such as copyrights, patents or research and development. However, at this juncture the study does not investigate this issue which would be a promising avenue in the future.

Table 6. Correlation between the variables in the year 2010

\begin{tabular}{lllllll}
\hline Variables & NCIA (IT) & TA & ROA & SUB (IT) & IIT & AIT \\
\hline NCIA (IT) & 1 & & & & & \\
TA & -0.1411 & 1 & & & & \\
ROA & $0.1301^{*}$ & $0.5522^{*}$ & 1 & & & \\
SUB (IT) & $0.4198^{*}$ & $0.1221^{*}$ & 0.0464 & 1 & & \\
IIT RATIO & $0.1581^{*}$ & $0.2408^{*}$ & 0.0129 & $0.3126^{*}$ & 1 & \\
AIT RATIO & $0.1249^{*}$ & -0.0206 & 0.0192 & 0.0452 & 0.0270 & 1 \\
\hline
\end{tabular}

Significant at $\alpha=0.01, * *$ Significant at $\alpha=0.05$, ** Significant at $\alpha=0.1 *$. 


\subsection{Linear Regression}

Table 7 presents the linear regression for the year 2010. From the table, the results indicate that only two ratios are significant enough with IT investments for the current year. The ratios are total assets (TA) and return on assets (ROA). All these ratios are significant at $\alpha=0.05$. The intercept of a point value is 37.2236 which show the positive slope with the value of ROA, SUB (IT), AIT RATIO and IIT RATIO. However, there is a negative slope of one independent variable which is LN (TA) with $\beta=-1.7131$ because the value of LN (TA) is greater than the value of IT investments which causes the intercept to be much larger. The same goes to ROA where its coefficient is at $\beta=.3339$ indicates that ROA is weakly associated with IT investments. Meanwhile, the results indicate that SUB (IT) is not significantly associated with IT investments. This might be due to the investments which are less focused on the sub (IT) as the number of sub (IT) is only $45 \%$ compared to the overall number of subsidiaries in the technology sector.

Training in this study is divided into two categories namely intermediate (IIT RATIO) and advanced trainings (AIT RATIO). Result for IIT RATIO shows, non-significant but result for AIT RATIO is significant with IT investments. Thus, for the second hypothesis $\left(\mathrm{H}_{2}\right.$ (a) $)$ it is partially supported, but with a weak association with IT investments.

Since the result of AIT RATIO also indicates a weak association with IT investments, thus the third hypothesis $\left(\mathrm{H}_{2(b)}\right)$ is supported but with a weak association with IT investments. It means that the smaller the number of advanced IT trainings the weaker its association with IT investments.

The weakest association is between AIT RATIO and IT investments. This is due to the fact that most of technology based companies invest more in purchasing new IT equipment such as computers rather than investing in purchasing software either for commercial purposes or for internal software development. For high technology companies, the use of IT hardware is something that could easily be managed by their IT people. The nature of IT hardware skills however is different with IT software skills that really need advanced IT skills to operate them. The rapid changes of software development over time requires specialized knowledge and IT skills that need to be upgraded through intensive training in order to ensure that their capabilities are aligned with the software's requirements; especially in commercial purposes, application software used in industrial automation, games, databases and business software. For this purpose, the exposure of employees to advance IT training generally will be the main focus of the company to further enhance their existing IT skills. Therefore, it can be concluded that the lesser the investments made in IT software the lesser the number of employees who will be exposed to advanced IT trainings. This reason can give a clear picture of the weakening association between advanced IT trainings and IT investments.

Table 7. Summary output of linear regression for the year 2010

\begin{tabular}{|c|c|c|c|c|c|c|c|c|}
\hline \multicolumn{9}{|c|}{ Regression Statistics } \\
\hline Multiple R & 0.5495 & & & & & & & \\
\hline R Square & 0.3019 & & & & & & & \\
\hline $\begin{array}{l}\text { Adjusted R } \\
\text { Square }\end{array}$ & 0.2664 & & & & & & & \\
\hline Standard Error & 5.5259 & & & & & & & \\
\hline Observations & 104 & & & & & & & \\
\hline \multicolumn{9}{|l|}{ ANOVA } \\
\hline & $d f$ & $S S$ & $M S$ & $F$ & $\begin{array}{c}\text { Significance } \\
F\end{array}$ & & & \\
\hline Regression & 5 & 1294.5462 & 258.9092 & 8.4790 & 1.0656 & & & \\
\hline Residual & 98 & 2992.4607 & 30.5353 & & & & & \\
\hline Total & 103 & 4287.0068 & & & & & & \\
\hline \multicolumn{9}{|l|}{ DV $=$ NCIA $($ IT $)$} \\
\hline & Coefficients & $\begin{array}{c}\text { Standard } \\
\text { Error }\end{array}$ & $t$ Stat & $P$-value & Lower 95\% & $\begin{array}{c}\text { Upper } \\
95 \%\end{array}$ & $\begin{array}{l}\text { Lower } \\
95.0 \%\end{array}$ & $\begin{array}{l}\text { Upper } \\
95.0 \%\end{array}$ \\
\hline INTERCEPT & 37.2236 & 8.0772 & 4.6085 & 1.2200 & 21.1946 & 53.2525 & 21.1946 & 53.2525 \\
\hline
\end{tabular}




\begin{tabular}{ccccccccc}
\hline LN (TA) & -1.7131 & 0.4529 & -3.7829 & $0.0003 * * *$ & -2.6118 & -0.8144 & -2.6118 & -0.81443 \\
ROA & 0.3339 & 0.1042 & 3.2053 & $0.0018 * * *$ & 0.1272 & 0.5407 & 0.1272 & 0.5407 \\
SUB (IT) & 0.6230 & 0.1346 & 4.6281 & 1.1300 & 0.3559 & 0.8902 & 0.3559 & 0.8902 \\
IIT RATIO & 0.0734 & 0.0702 & 1.0459 & 0.2982 & -0.0659 & 0.2127 & -0.0659 & 0.2127 \\
AIT RATIO & 5.3915 & 4.1725 & 1.2922 & $0.1993 *$ & -2.8887 & 13.6717 & -2.8887 & 13.6717 \\
\hline
\end{tabular}

Significant at $\alpha=0.01, * * *$ Significant at $\alpha=0.05, * *$ Significant at $\alpha=0.1 *$.

\subsection{Summary of Findings}

The summary of the analysis is exhibited in Table 8 below.

Table 8 . Summary of findings

\begin{tabular}{ccc}
\hline & Hypotheses & Results \\
\hline $\mathrm{H}_{1}$ & $\begin{array}{c}\text { IT-based companies are actively involved in IT investments } \\
\text { compared to engineering-based companies. }\end{array}$ & Supported \\
$\mathrm{H}_{2(\text { a) }}$ & $\begin{array}{c}\text { There are associations between IT related trainings and IT } \\
\text { investments in Malaysian technology companies. }\end{array}$ & Partially supported but weak association \\
$\mathrm{H}_{2(\text { b) }}$ & $\begin{array}{c}\text { The more advanced IT trainings, the more investments in IT made } \\
\text { by technology based companies. }\end{array}$ & Supported but weak association \\
\hline
\end{tabular}

\section{Conclusion and Discussion}

The purpose of this study is to investigate whether there are association between IT trainings and IT investments in the Malaysian technology companies. Five variables were used namely TA, ROA, SUB (IT) to interpret the IT investments while IIT RATIO and AIT RATIO were used to interpret the IT trainings. These dimensions were examined on the Malaysian public listed companies based on technology based companies.

The data served the expansion of the view that IT related trainings can be viewed as an important element in impacting IT investments as discussed by several prior studies which indicate that IT investments are often associated with increased in training effort (Bartel et al., 1987; Laudon \& Laudon, 1998; Brynjolfosson \& Hitt, 1998; Bartel \& Sicherman, 1998; Arabsheibani et al., 2004; Loo et al., 2005; Moriones \& Lopez, 2007). Through effective IT related trainings applied to all employees, it appears to predict IT investments. In this study, two types of IT related trainings namely, intermediate IT trainings and advanced IT trainings are highlighted to investigate on how these trainings can help to predict IT investments incurring in companies.

The result of the first hypothesis shows that IT-based companies tends to invest more in IT compared to engineering-based companies. Thus, the findings support the expectation of the first hypothesis since IT-based companies are more involved in the use of IT components either in their processes, delivery, and display of information electronically, as well as in producing equipment, software and services that enable those IT activities (OECD, 2008). However, these findings cannot be supported by other empirical results since there are no evident to prove that the IT-based companies are more involved in IT investments.

The result of the second hypothesis can be concluded that the associations between IT related trainings and IT investments are not significant enough. Only a weak association was found in AIT RATIO while IIT RATIO was found insignificant with IT investments. Thus, the result can be concluded that the second hypothesis is supported but not significant enough. On the contrary, this result is not supporting the empirical results which indicated that IT investments are often associated with increased in IT training efforts because of the limited sample size. The same goes to the third hypothesis, AIT RATIO found significant but a weak association with IT investments. Although the data used is small, but still there is a weak support for AIT RATIO.

The results are encouraging in that this study has proved the ability of IT related trainings to predict its association with IT investments. However, the results are not significant enough and it is found that there are weak associations between IT related trainings and IT investments. Further study is needed to explore the significant association between IT related trainings and IT investments by considering some recommendations to improve the results. Firstly, have more samples. The number of sample of population and IT trainings may be increased by expanding the criteria to more sectors by taking into account the data on IT trainings based on at least of two or three years before the IT investments were made during the current year. Apart from that, the number of 
employees may also be used by getting the data through questionnaires distributed to each company of the sectors involved. The questionnaire will emphasize on the number of employees in the IT department and non-IT department. The data obtained may help the researcher to better explore the extent to which the number of employees in both departments are actively involved in attending IT training programs provided by their companies.

\section{References}

Abas, M. G. (2005). ICT usage in Malaysia: A study on its economy impact. Ph.D Thesis, Graduate School of Global Information and Telecommunication Studies (GITS), Waseda University, Japan.

Arabsheibani, G. R., Emami, J. M., \& Marin, A. (2004). The Impact of Computer Use on Earnings in the UK. Scottish Journal of Political Economy, 51(1), 82-94.

http://dx.doi.org/10.1111/j.0036-9292.2004.05101005.x

Ashrafi, R., \& Murtaza, M. (2008). Use and Impact of ICT on SMEs in Oman. The Electronic Journal Information Systems Evaluation, 11(3), 125-138.

Atasoy, H. (2011). ICT Skills and Employment Opportunities. The Quarterly Journal of Economics, 1-25.

Auer, K. (1995). Small talk training as innovative as the environment. Communications of the ACM, 38(10), 115-117. http://dx.doi.org/10.1145/226239.226266

Baldwin, J. R., \& Diverty, B. (1995). Advanced Technology Use in Canadian Manufacturing Establishments. Working Paper, No. 85, Microeconomics Analysis Division, Statistics Canada, Ottawa. http://dx.doi.org/10.1787/9789264026780-9-en

Baldwin, J. R., Sabourin, D., \& Smith, D. (2004). Firm Performance in the Canadian Food Processing Sector: The Interaction between ICT Advanced Technology Use and Human Resource Competencies in OECD. The Economic Impact of ICT-Measurement, Evidence and Implications, OECD.

Bartel, A. P., \& Sicherman, N. (1998). Technological Change and the Skill Acquisition of Young Workers. Journal of Labor Economics, 16(4), 718-755. http://dx.doi.org/10.1086/209904

Bass, J. M. (2007). A Developmental Model of Basic IT Skills for Pre-Service Trainee Teachers. IEEE/ ACM International Conference on Information and Communication Technologies and Development, 2, 183-192.

Bates, R. A., Holton, E. F., \& Seyler, D. L. (1996). Validation of a transfer instrument. Proceedings of the Academy of Human Resource Development, 426-433.

Berman, E., Bound, J., \& Griliches, Z. (1994). Changes in the demand for skilled labour within U.S. manufacturing: Evidence from the Annual Survey of Manufactures. Quarterly Journal of Economics, 109(2), 367-398. http://dx.doi.org/10.2307/2118467

Brynjolfsson, E. (1993). The productivity paradox of information technology: Review and assessment. Communications of the ACM, 36(12), 67-77. http://dx.doi.org/10.1145/163298.163309

Brynjolfsson, E. (1994). Information assets, technology, and organization. Management Science, 40(12), 1645-1662. http://dx.doi.org/10.1287/mnsc.40.12.1645

Brynjolfsson, E., \& Hitt, L. (1995). Information Technology as a Factor of Production: The Role of Differences among Firms. Economics of Innovation and New Technology (Special No. on Information Technology and Productivity Paradox), 3(4), 183-200. http://dx.doi.org/10.1080/10438599500000002

Brynjolfsson, E., \& Hitt, L. (2000). Beyond Computation: Information Technology, Organizational Transformation and Business Performance. Journal of Economic Perspectives, 14(4), 23-48. http://dx.doi.org/10.1257/jep.14.4.23

Brynjolfsson, E., \& Hitt, L. M., (1998). Beyond the Productivity Paradox — Computers is the Catalyst for Bigger Changes. Communications of the ACM, 41(8), 49-55. http://dx.doi.org/10.1145/280324.280332

Colecchia, A., \& Schreyer, P. (2002). ICT Investment and Economic Growth in the 1990s: Is the United States a Unique Case? A Comparative Study of Nine OECD Countries. Review of Economics Dynamics, 5(2), 408-442. http://dx.doi.org/10.1006/redy.2002.0170

Connolly, D. (1999). Understanding information technology, investment decision making in the context of hotel global distribution systems: A multiple-case study. Unpublished Doctoral Dissertation, Department of Hospitality \& Tourism Management, Virginia Polytechnic Institute and State University. 
Davey, S. (2007). The Organizational Benefits of Training and How to Get Them.

Fairfax County Public Schools. (2004). Information Technology Training Specialist.

Fisher, A. (1993). A global concept-virtual companies. The Financial Times, 1-12.

Ford, J. R., \& Weissbein, D. H. (1997). Transfer of Training: An Updated Reviewand Analysis. Performance Improvement Quarterly, 10(2), 22-41. http://dx.doi.org/10.1111/j.1937-8327.1997.tb00047.x

Frodeman, R., Klein, J. T., \& Mitcham, C. (2010). The Oxford Handbook of Interdisciplinarity. UK, Oxford: Oxford University Press.

General Accounting Office. (2000). Information Technology Investment Management: An Overview of GAO's Assessment Framework. Accounting and Information Management Division, 1-10.

Goktas, Y., Yildirim, S., \& Yildirim, Z. (2009). Main barriers and possible enablers of ICTs integration into pre-service teacher education programs. Educational Technology \& Society, 12(1), 193-204.

Gorriz, C. G., \& Castel, A. G. (2010). The relationship between human resources and information and communication technologies: Spanish firm-level evidence. Journal of Theoretical and Applied Electronic Commerce Research, 5(1), 11-24.

Hall, B. H., Lotti, F., \& Mairesse, J. (2011). Evidence on the impact of R\&D and ICT investment on innovation and productivity in Italian firms. National Bureau of Economic Research, Inc, 1-37.

Hamidi, F., Meshkat, M., Rezaee, M., \& Jafari, M. (2011). Information Technology in Education. Procedia Computer Sciences, 3, 369-373. http://dx.doi.org/10.1016/j.procs.2010.12.062

Hazani, N. (2004). Hubungan antara pemindahan latihan dengan factor individu dan persekitaran kerja: Satu kajian kes di TNB kawasan Johor Bahru, Johor. Master's thesis, Universiti Teknologi Malaysia, Faculty of Management and Human Resource Development.

Hubbard, P. (2005). A review of subject characteristics in CALL research. CALL Journal, 18(5), 351-368. http://dx.doi.org/10.1080/09588220500442632

Khor, W. L. (1999). Amalan penilaian pelaburan teknologi maklumat di bank-bank perdagangan Malaysia. Master's thesis, Universiti Teknologi Malaysia.

Knowledge Society Agency (UMIC). (2008). New Survey Data about the Information Society in Portugal 2008. Ministry of Education and Science.

Kodakanchi, V., Abuelyaman, E., Kuofie, M. H. S., \& Qaddour, J. (2006). An Economic Development Model for IT in Developing Countries, Electronic Journal of Information Systems in Developing Countries, 28(7), $1-9$.

Kolding, M., \& Kroa, V. (2007). E-skills: The key to employment and inclusion in Europe. Technical report, IDC White Paper, 1-13.

Mann, K. (2003). A Snapshot of Outdoor Leadership Preparation Opportunities in Australia. 13th National Outdoor Education Conference Proceedings, 121-127.

Moriones, A. B., \& Lopez, F. L. (2007). A firm level analysis of determinants of ICT adoption in Spain, Technovation, 27(6-7), 352-366. http://dx.doi.org/10.1016/j.technovation.2007.01.003

Morris, P. W. G. (2003). The irrelevance of project management as a professional discipline. 17th World Congress on Project Management. Moscow: International Project Management Association.

OECD. (2008). OECD Information Technology Outlook. France, Paris: Chapter 7, OECD,

OECD. (2003). ICT and Economic Growth-Evidence from OECD Countries, Industries and Firms. France, Paris.

OECD. (2004). The Economic Impact of ICT- Measurement, Evidence and Implications. OECD Economic Studies, 38.

Paytas, J., \& Berglund, D. (2004). Technology Industries and Occupations for NAICS Industry Data. Carnegie Mellon University Center for Economic Development.

Pravitt. (1984). Different Timeliness for Different Technologies: Evidence from the Advanced Technology Program. NIST of the U.S. Commerce Department. NISTIR 6917. Retrieved from http://www.atp.nist.gov/eao/ir-6927/chapt3.htm 
Rocheleau, B. (2006). Public Management Information Systems. Idea Group Publishing.

Shafique, F., \& Mahmood, K. (2010). The Role of Educational Information Systems for Survival in Information Society and the Case of Pakistan. The International Information \& Library Review, 42, 164-173. http://dx.doi.org/10.1016/j.iilr.2010.07.007

Sharpe, A. (2006). The relationship between ICT investment and productivity in the Canadian economy: A review of the evidence. Centre for the Study of Living Standards Research Reports, 1-85.

Stair, R. M., \& Reynolds, G. W. (1999). Management information systems (4th ed.). Cambridge: Mass Publisher.

Sullivan, J. M., Benton, J. L., Sandeman, D. C., \& Beltz, B. S. (2007). Adult Neurogenesis: A Common Strategy Across Diverse Species. Journal of Comparative Neurology, 500, 574-584. http://dx.doi.org/10.1002/cne.21187

Tapscott, D. (1996). The Digital Economy. New York: McGraw-Hill.

Telem, M., \& Pinto, S. (2004). Information Technology's Impact on School-Parents and Parents-Student Interrelations: A case study. Computers \& Education, 47, 260-279. http://dx.doi.org/10.1016/j.compedu.2004.10.008

Turcotte, J., \& Rennison, L. W. (2004). The Link between Technology Use, Human Capital, Productivity and Wages: Firm-level Evidence. InternationalProductivity Monitor, Number 9, fall, 25-36.

Waema, T. M. (2002). ICT Human Resource Development in Africa: Challenges and Strategies. African Technology Policy Studies Network Publishers, 10, 1-16.

Wilke, J. D. (2006). The importance of employee training. Jacksonville Business Journal.

Wilson, M., de Zafra, D. E., Pitcher, S. I., Tressler, J. D., \& Ippolito, J. B. (1998). Information Technology Security Training Requirements: A Role-and Performance-Based Model. NIST Special Publication, 800(16). $1-168$.

Zaharias, P., \& Poulymenakou, A. (2003). Identifying training needs for ICT skills enhancement in South-Eastern Europe: Implications for designing web-based training courses. Journal of Educational Technology \& Society, 6(1). Retrieved from http://www.ifets.info/journals/6_1/zaharias.html

\section{Copyrights}

Copyright for this article is retained by the author(s), with first publication rights granted to the journal.

This is an open-access article distributed under the terms and conditions of the Creative Commons Attribution license (http://creativecommons.org/licenses/by/3.0/). 